\title{
On economic inequality and schools of economic thought
}

\section{Alfredo Félix Blanco*}

\section{Summary}

The question of inequality is not new in the history of economic thought; from the very birth of political economy as an independent discipline, the issues of the distribution of wealth, poverty and economic inequality were present.

Obviously, the subject exceeds the disciplinary field of the economists because, as Piketty has pointed out at the beginning of his book: "... the distribution of wealth is too important an issue to be left to economists, sociologists, historians, and philosophers. It is of interest to everyone, and that is a good thing" (Piketty 2013 [2017], p. 2).

However, among economists the issue has become more important in recent years because of the deepening of the level of inequality that has accompanied the process of growth and globalization of the world economy.

Transformations that accompanied the emergence of capitalism since the nineteenth century raised the first questions, and its evolution throughout the twentieth century and in the current century have faced different responses from different economic schools.

Some very relevant questions which political economy can help answer are: Does capitalism inevitably lead to greater inequality? Or does the market mechanism itself tend to reduce inequalities? Does greater inequality contribute to economic growth? Or does inequality just cause cyclical crises? This last two questions are very relevant for less developed (emerging?) countries.

The history of economic thought shows us that economists have given different answers, at different times of the evolution of economic ideas.

In this paper the vision that the main thinkers of political economy have had on this issue is reviewed. Among the latter are the classical school, the extreme optimism of Adam Smith and Jean B. Say, the doubts on the future of David Ricardo, the negative predictions of Malthus and the eclecticism of Mill. Marx and his ideas about the fall of capitalism. Neoclassical blind confidence in the markets and Keynes and the capitalist crises.

Lastly, a final consideration is made about the reality of inequality in the 21 st century, neoliberalism and the commitment of economists as intellectuals.

Keywords: Inequality, distribution and poverty

JEL: B, BOO

\section{INTRODUCTION}

The issue of inequality is not new in the history of economic thought; from the very birth of political economy as an independent discipline, the issues of wealth

\footnotetext{
* Universidad Nacional de Córdoba.
} 
distribution, poverty and economic inequality have been present.

Obviously, the subject exceeds the disciplinary field of the economists because, as Piketty has pointed out at the beginning of his book:

"... the distribution of wealth is too important an issue to be left to economists, sociologists, historians, and philosophers. It is of interest to everyone, and that is a good thing" (Piketty, 2013, [2017], p. 2).

This paper is not exhaustive in any sense; only some of the main authors and some of their ideas are reviewed.

The ideas associated with the problem of inequality have been present since the Greek philosophers wrote about Justice.

In Plato we can read that Justice is one of the main virtues of a man and that inequality must have a limit: "The kind of law that I would enact as proper...would be this:... that none of its citizens should be in a condition of poverty or wealth more painful, since both conditions produce these results; consequently, the legislator must now declare a limit for both conditions" (Plato, 356? B.C., Book V, p. 379).

Aristotle, who regarded the inequality between two men as natural, believed that Justice was a central matter to order a society.

"Since then some men are slaves by nature, and others are freemen, it is clear that where slavery is advantageous to any one, then it is just to make him a slave." (Aristotle, 330-323 B.C.,Book I, Chapter V), and: "There is then in all persons a natural impetus to associate with each other in this manner, and he who first founded civil society was the cause of the greatest good; for as by the completion of it man is the most excellent of all living beings, so without law and justice he would be the worst of all, for nothing is so difficult to subdue as injustice in arms: but these arms man is born with, namely, prudence and valour, which he may apply to the most opposite purposes, for he who abuses them will be the most wicked, the most cruel, the most lustful, and most gluttonous being imaginable; for justice is a political virtue, by the rules of it the state is regulated, and these rules are the criterion of what is right"-1 (Aristotle, 330-323 B.C., Book I, Chapter II).

The most widespread Western religions have shown great concern for inequality between men and have condemned social injustices, even if they coexist with and often participate in power structures that are clearly unjust and that generate great social and economic inequalities.

In the Middle Ages, Scholastics discussed a lot about Justice; all Scholastic works dealt with moral or ethical subjects. The "Summa Theologiae" wrote by Thomae de Aquino is the archetypal Scholastic book. Scholastics wondered whether it is right to sell a good for a higher price than that for which it was bought, whether it is right to lend money with interest, etc. These are the typical problems that Scholastics discussed.

Obviously, moral and ethical considerations are necessary when equality is the subject. Sometimes modern economists forget this important matter.

However, among economists the issue has become more important in recent years because of the deepening inequality that was caused by the process of economic growth and globalization.

Structural transformations that produced the emergence of capitalism since the nineteenth century raised the first questions, and its evolution throughout the twentieth century and in the current century have received different answers from different schools of political economy.

\footnotetext{
${ }^{1}$ Emphasis added
} 


\section{Articles}

The history of economic thought helps us to understand why the economists have given different answers, at different times throughout the evolution of economic ideas.

Some very relevant questions which political economy can help answer are: Does capitalism inevitably lead to greater inequality? Or does the market mechanism itself tend to reduce inequalities? Does greater inequality contribute to economic growth? Or does inequality just cause cyclical crises? The last two questions are very relevant for less developed countries.

\section{WHAT KIND OF INEQUALITY ARE WE TALKING ABOUT?}

The word "inequality" can refer to natural differences or to social differences among men; the former (sex, race, etc.) are beyond the reach of human will, but the latter (the social differences) depend fundamentally on the social organization and actions of human beings.

A basic characteristic of human beings is diversity, so when we speak about inequality we must be very specific, saying which variables are relevant to judge the equality level of a situation.

Amartya Sen (1992) pointed out a very relevant idea when he asked: "equality of what?". In the words of Sen:

"The crucial role of the question 'equality of what?' suggests that we can see the disputes between different schools of thought in terms of what they respectively take to be the central social exercise in which equality is to be demanded...The demand for equality in terms of one variable entails that the theory concerned may have to be non-egalitarian with respect to another variable..." (Sen, 1992, preface, p. IX).

Within the field of knowledge of social science, economic inequalities are very important; they influence other dimensions (for example political or power differences) and can be considered from different points of view. Economic inequalities viewed through the wealth differences and through the income differences are related but they are not the same phenomenon. It seems rational to think that wealth inequality implies income inequality, but they do not have the same characteristics and economic effects. A world without poverty would be a more equal world, and probably would have less wealth inequality. Needless to add, it would be a better world than ours.

In this paper the (general) vision that some of the main thinkers of political economy have had on economic inequality is reviewed.

This review is done without any consideration of the empirical problems that these economists had when they analysed the phenomenon. There are many ways to measure economic income inequality, two of the main tools to do it are the following: the Gini Index and the relation between income of the first and the last decile of income distribution. We will only say that each instrument used to measure inequality assumes different definitions of the phenomenon and has its own strengths and weaknesses in the analysis of inequality.

As it was mentioned above, inequality began to be a relevant topic with the birth of capitalism and the generalization of private property that came with it. Hence in the works of the Classical School we can find many references to this topic.

\section{THE CLASSICS ON INEQUALITY}

Adam Smith, David Ricardo and Thomas Malthus saw poverty and inequality as the consequence of natural laws that they were trying to discover and understand. Jean B. Say, the main French classic, also thought that the proportions in which the product 
is distributed among different individuals was determined by a natural law. In Say (1803) the second book is entitled "OF THE DISTRIBUTION OF WEALTH" and it begins with value theory and ends stating that "Thus, each class receives its respective share of the total value produced; and this share composes its revenue."(Say, 1803, p. 314).

Although they had important differences, these three remarkable classical thinkers agreed that the spontaneous development of capitalism with no intervention of the State would make a better society possible, but they knew that inequality would be a serious problem. Adam Smith, despite his optimism about the future of capitalism, was concerned not only about poverty but also about economic inequalities.

"Is this improvement in the circumstances of the lower ranks of the people to be regarded as an advantage or as an inconvenience to the society? The answer seems at first sight abundantly plain. Servants, labourers, and workmen of different kinds, make up the far greater part of every great political society. But what improves the circumstances of the greater part can never be regarded as an inconvenience to the whole. No society can surely be flourishing and happy, of which the far greater part of the members are poor and miserable. It is but equity, besides, that they who feed, clothe, and lodge the whole body of the people, should have such a share of the produce of their own labour as to be themselves tolerably well fed, clothed, and lodged". 2 (Smith, 1776 [1976] Book I. CHAPTER VIII, $p$ 96).

It is very clear that Smith, a moral philosopher, understood that poverty and economic inequality needed an ethical and a moral consideration, even though he thought that they seemed to be a natural consequence of social development, and he was very concerned with these problems.

As it is well known, David Ricardo thought that the main subject of political economy was to discover the laws of the distribution of wealth in capitalism. He wrote: "To determine the laws which regulate this distribution, is the principal problem of the Political Economy..." (Ricardo,1821 [2001], Preface, p. 5). His works focused on problems related to poverty and inequality but with great differences from Smith. He was less optimistic than Smith and he did not believe in the "Smithian social harmony", because he saw contradicting interests between the social classes (particularly between the interests of landlords and the interests of the other social classes).

Ricardo, in the third edition of his Principles, added a chapter called "On machinery" where he analysed the impact of substitution of machinery for men and its consequences on income distribution (Ricardo, 1821 [2001], Chapter 31). He did not hesitate to affirm that it was "...often very injurious to the class of labourers" (Ricardo, 1821 [2001], Chapter 31, p. 283). Although in the same chapter he also expressed:

"The statements which I have made will not, I hope, lead to the inference that machinery should not be encouraged. To elucidate the principle, I have been supposing, that improved machinery is suddenly discovered, and extensively used; but truth is, that these discoveries are gradual, and rather operate in determining the employment of the capital which is saved and accumulated, than in diverting capital from its actual employment" (Ricardo, 1821 [2001], Chapter 31, p. 289).

Ricardo tried to discover the laws of distribution because, if he could explain

\footnotetext{
2 Emphasis added.
} 


\section{Articles}

the level and tendency of profit, it would be possible to understand capital accumulation and economic growth. Hence the relationship between his theory of distribution and the long term evolution of the capitalist economy is quite clear and obvious.

Malthus, looking at the social conditions of his time, believed that the causes of poverty were just inevitable consequence of the laws of population growth. His Essay (Malthus, 1798) was a very relevant influence not only on Ricardo but also on the entire classic paradigm of political economy. Malthus also saw poverty as a great problem, as a natural one.

"But as from the laws of our nature some check to population must exist, it is better that it should be checked from a foresight of the difficulties attending a family and the fear of dependent poverty than that it should be encouraged, only to be repressed afterwards by want and sickness" (Malthus, 1798, Chapter V. p. 90).

Both, Ricardo and Malthus fought against the Poor Laws thinking that those kind of tools could not solve the problem ${ }^{3}$ and Robert Torrens clearly explained the reason because of which a theory of distribution was so relevant:

"The study of Political Economy, if it did not teach the way in which labour may obtain an adequate reward, might serve to gratify a merely speculative curiosity, but could scarcely conduce to any purposes of practical utility...Political Economy is not..., the appropriate science of the stateman and the legislator; it is peculiarly end emphatically, the science of the people" (Torrens, 1834, pp. 1-2).
In the middle of the $19^{\text {th }}$ century many thinkers saw that the future of happiness, equality and justice had been just a dream; the optimistic view of the classics began to crumble. Many studies of the period show clearly that wages dropped, the situation of the working classes deteriorated and poverty significantly increased.

For example Piketty thinks that: "In fact, all the historical data at our disposal today indicate that it was not until the second half-or even the final third-of the nineteenth century that a significant rise in the purchasing power of wages occurred. From the first to the sixth decade of the nineteenth century, workers' wages stagnated at very low levels-close or even inferior to the levels of the eighteenth and previous centuries" (Piketty, 2013 [2017] p. 9).

One of the most important economist of Classical school, John Stuart Mill, abandoned the idea that wealth distribution was determined by natural laws.

Particularly, he postulated that there was no distribution laws similar to natural laws. Distribution of wealth, for him, was a matter of institutional character and not a natural fact.

"The laws and conditions of the Production of wealth partake of the character of physical truths. There is nothing optional or arbitrary in them...It is not so with the Distribution of wealth. That is a matter of human institution solely. The things once there, mankind, individually or collectively, can do with them as they like. They can place them at the disposal of whomsoever they please, and on whatever terms...The rules by which it is determined, are what the opinions and feelings of the ruling portion of the community make them, and are very different in different ages and countries; and might be still more different,

\footnotetext{
${ }^{3}$ Malthus disagreed with Ricardo about the possibilities of a generalized crisis of the system. He thought that crises were possible because of insufficient effective demand. Many years after, the term "effective demand" was used to explain capitalist crises by John M. Keynes who had a high concept of Malthus. See Keynes (1933)
} 
if mankind so chose" (Mill, 1848, Book II, Chapter l, p.199).

Summing up, we can say that the Classical school did not ignore the phenomenon of inequality and poverty that characterized the birth of modern capitalism. The Classics were concerned about the subject and believed in the natural character of the laws that explained it. Their vision of the natural character of poverty and economic inequality underwent modifications from his founder (Smith) to his last exponent (Mill). The seventy-two years from Smith's Wealth of Nations until Mill's Principles was published, was a period of remarkable transformations of the economic system, the questions and answers could not remain unchanged for these sharp thinkers.

The puzzle for the Classical school was to find the economic laws that explained exchangeable value because they wanted to understand the origin of wealth and its distribution. That is the main reason because of which inequality was always present in their economic analysis.

\section{SOCIALIST WRITERS}

The situation of poverty in the nineteenth century, a radical interpretation of the Utilitarian postulates ("the greatest happiness for the greatest number"), and the disappointment with the "liberal dream" explain the birth of socialist ideas that try to build a more egalitarian society.

However, many years before there were many philosophers, politicians and pamphleteers who had imagined new forms of social organization. Before socialist thinkers, many authors wrote about social injustice and inequality. Among them it is essential to quote Jean Jacques Rousseau and his: "Discours sur l'Origine et les fondements de l'inegalité parmi les hommes" that he wrote in 1754 . He criticized the idea of private property because, with private property, not only civil society but also inequality began.

"The first man who, having enclosed a piece of ground, bethought himself of saying this is mine, and found people simple enough to believe him, was the real founder of civil society. From how many crimes, wars and murders, from how many horrors and misfortunes might not any one have saved mankind, by pulling up the stakes, or filling up the ditch, and crying to his fellows, 'Beware of listening to this impostor; you are undone if you once forget that the fruits of the earth belong to us all, and the earth itself to nobody' "

(Rousseau, 1754, Second Part, p. 23). ${ }^{4}$

The nineteenth century is the period when discussions about inequality, poverty and how to deal with these problems of capitalism became more important for political economy. Since the second decade of the nineteenth century, and from different ideological trends (romantic, nationalist, historicist and socialist), opinions that attempted to demonstrate the limitations of the classical approach emerged, even though none ended with the hegemony of the classical school and only Marx transcended his time.

The ideas of non-Marxist socialists were more related to social criticism than to a theory that could explain the economic reality. However, they had an important influence on Marx, particularly the French socialists.

Ricardian socialists, Utopics socialists and finally Marx and his followers were the most important authors talking about poverty and inequality in that period. Among the Ricardian socialists works, Thompson (1824), Gray (1825) [1972], Bray (1839) and Hodgskin

${ }^{4}$ Emphasis added. Rousseau wrote this work because of a subject proposed by the Academy of Dijon: "What is the origin of inequality among men, and is it authorised by natural law?" 


\section{Articles}

(1825) [1922] should be highlighted. They adopted the Ricardian labour theory of value but they developed a radical interpretation of it and, as many other, they left the liberal economic ideas and became socialists.

Sismondi, Saint Simon, Fourier, Proudhon, and other pre-Marxist authors, had a lot of ideological and practical differences about what to do, but all of them agreed that inequality and the pauperization of the working classes were inevitable under capitalist conditions. Their main works were: Sismondi (1819), Saint Simon (1825 ), Fourier (1822 ) and Proudhon (1840).

Many non-Marxist socialist thinkers of the nineteenth century were initially liberals who agreed with the postulates of the Classical school, but became opponents of these theories and questioned the social reality of their time. For example, Jean Charles Léonard De Sismondi (1773-1842) was initially a fervent admirer of liberal ideas (especially Smith's), but later reacted strongly against the negative effects of the capitalism of his time. The impossibility of the workers to obtain wage improvements, the poor working conditions and the deterioration of quality of life of the workers were the main causes of Sismondi's reaction.

In 1819, the year of the second edition of Ricardo's Principles, Sismondi published his Nouveaux Principes d'economie politique, and claimed that the only thing that "laissez-faire" would achieve was to make the rich even richer and the poor more miserable.

$\mathrm{He}$ criticized the excess of abstraction of classical political economy, denying the harmony and the coincidence between the individual and collective interest. His concern about economic crises, and his view that machinery increased the production without having enough demand, led him to postulate that technological progress should be slowed down to avoid imbalances.

Finally, Karl Marx, the great enemy of capitalism, thought that that poverty and inequality were a consequence of the private property of the means of production. He believed that capitalism's own contradictions would destroy the capitalist system. The working class had the historic mission to bring to an end the unjust economic system and to build a new society without man exploitation. Marx is the most important socialist thinker who assigned significant importance to inequality to explain the evolution of the capitalist mode of production. Marx fought all his life against capitalism and he thought that inequalities between social classes were inevitable under capitalism. It is very important to remark that Marx thought that it was a mistake to think that it was possible to avoid inequalities under capitalism. In his Critique of the Gotha Programme (Marx, 1891) criticized the following claim:

"And since useful labor is possible only in and through society,-the proceeds of labor belong unabridged, in equal right, to all the members of society" (Marx, 1891, $p$. 21). ${ }^{6}$

According to Marx that claim was impossible and wrong under capitalist condition:

"Indeed, this has been the regular claim made by the champions of each succeeding social system. First come the claims of the government and all that hangs thereby, since it is the social organ for the maintenance of the social order; next come the claims of the various sorts of private property, for the various sorts of private property are the foundations of society, etc. It is plain, such

\footnotetext{
${ }^{5}$ It was written in April or early May, 1875 and published by Engels in 1891.

${ }^{6}$ Emphasis added.
} 


\section{Articles}

hollow phrases can be turned and twisted at will" (Marx, 1891, pp. 21-22).

However it is very relevant to say that Marx (like Engels) did not agreed with egalitarian ideas.

"The right of the producers is proportional to their contribution of labor; the equality consists in this, that the right is measured by an equal standard: labor.

However, one person is physically or intellectually superior to the other, and furnishes, therefore, more labor in the same time, or can work a longer time; and in order to serve as a measure, labor must be determined according to duration or intensity, otherwise it would cease to serve as a standard. This equal right is unequal right for unequal labor. It does not recognize class distinctions, because every one is only a workingman like everybody else; but it tacitly recognizes unequal individual endowment, and hence, efficiency, as natural privileges. It is, therefore, in its substance, a right of inequality, like all right... Moreover, one workingman is married, the other is not married; one has more children than the other, etc., etc. Hence, with equal contribution of labor and, therefore, equal shares in the social consumption-fund, the one receives actually more than the other, the one is richer than the other, etc. In order to avoid all these shortcomings right would have to be not equal, but unequal. But these shortcomings are unavoidable in the first phase of Communist society, as it has just issued from capitalist society after long travail.

In the higher phase of Communist society,...- only then may the limited horizon of capitalist right be left behind entirely, and society inscribe on its banners: "From everyone according to his faculties, to
On Economic Inequality and Schools of Economic Thought

everyone according to his needs!" (Marx, 1891, p. 31).

To sum up, in relation to the object of this article, we can affirm that the issue of economic inequality among men was clearly visualized by the socialist authors as inherent to the system, although they proposed different models of overcoming the capitalist mode of production.

\section{NEOCLASSICAL SCHOOL AND CONFIDENCE IN THE MARKET}

Neoclassical Revolution gave to economists a lot of new sources for their toolbox, but it was a very drastic change of the dominant paradigm of political economy; it implied a new definition of the object to be studied by the discipline and the Neoclassical school became the new mainstream. This situation would stay unchanged until the birth of Keynesian economics in the third decade of the $20^{\text {th }}$ century.

William S. Jevons with his Theory of Political Economy (Jevons, 1871, [1888]), Leon Walras with his Éléments d'économie politique pure, ou théorie de la richesse sociale (Walras, 1874) [2014]) and Carl Menger with his Principles of Economics (Menger, 1871 [2007]) are the names associated with the change of this paradigm. Alfred Marshall, who was teaching similar ideas in Cambridge, published "Principles of Economics" in 1890 (Marshall, 1890 [1920]).

The neoclassic paradigm brought new questions, and new answers, but many times forgot problems of distribution too. Of course there were many exceptions. Vilfredo Pareto, for example, studied distribution problems and he was very critical with the distribution theory based in the marginal productivity. His ideas and analysis on the issue of inequality can be reviewed in Pareto (1896-7). In the 20th century Professor Pigou was another 


\section{Articles}

very remarkable exception (see Pigou, 1920 [1932]).

The core question to be analysed was how to optimize the allocation of scarce economic resources. Neo-classical economists abandoned the labour theory of value $^{7}$, rediscovered the idea of a utility function, and developed a theory of prices to explain the maximization of the utility for the consumers and the profits of the companies. In the new paradigm, companies have a production function and make decisions in a context of perfect certainty, seeking to maximize their own benefit. Under such conditions the whole the product is distributed among the production factors in proportion to their marginal productivities.

It was really a big methodological and epistemological change.

Even though Marshall reflected on problems of poverty, income distribution and inequalities, his main contribution to economic theory was the analysis of the conditions to establish that a market is competitive and the process to determine price determination in those markets.

For Neoclassical economists the distribution problems of society would be solved by self-adjusting market mechanisms, the nice dream of Classical economists seemed to be back.

\section{THE 20TH CENTURY}

In the first decades of the $20^{\text {th }}$ century neoclassical ideas were the mainstream of political economy. Despite the differences between "Marshallians" and "Walrassians" the equilibrium theory was the hegemonic paradigm, at least until the fourth decade of the century. A brief and clear description of the situation in the first decades of the 20th century can be see in Napoleoni (1963), Chapter I.

Besides the Keynesian critiques, there were many economists that saw the problems of the Neoclassical theory. ${ }^{8}$

Keynesian economics meant a great critique and showed the weakness of that theoretical view. However, despite the Keynesian critique, the Neo-classical paradigm left its mark on the mainstream of modern economics. It is very important to highlight that the alleged ideological neutrality of the mainstream has often led many economists to take refuge in an ivory tower without committing to solving the problems of their time.

Although Keynes (Keynes, 1936) did not explicity discuss in almost any chapter of his General Theory income distribution, he saw that inequality of income distribution was really a great problem of the capitalist system. He wrote, in the last chapter of his famous General Theory:

"The outstanding faults of the economic society in which we live are its failure to provide for full employment and its arbitrary and inequitable distribution of wealth and incomes. The bearing of the foregoing theory on the first of these is obvious. But there are also two important respects in which it is relevant to the second". (Keynes,1936, p. 372).

In this chapter, and in relation with inequality, besides criticism of pre-Keynesian

\footnotetext{
${ }^{7}$ Marshall tried to reinterpret and conciliate the Ricardian theory of value with the new ideas of Neo-classical thinkers. See. Marshall (1890) [1920]. Appendix I. ("Ricardo's Theory of Value").

${ }^{8}$ It is worth mentioning: a) the attack to the assumption of perfect competition (P. Sraffa, J. Robinson, E. Chamberlain) , b) The critics to the assumption of rational and maximizing economic agent and c) The attack to the idea of an aggregate production function has been strongly criticized too. The so called "Cambridge Capital Theory Controversy" is not within the scope of this paper but it is very relevant not only for the history of economic thought but for the economic theory. See Cohen and Harcourt (2003).
} 
confidence in laissez faire, Keynes highlighted two important topics. On the one hand, as we quoted before, he saw that inequality was one of the main problems of the economic system (the other problem, was unemployment and it is a cause of inequality too). On the other hand, he pointed out that the relationship between poverty and growth was not the one that Neoclassics assumed. An unequal income distribution is not good for growth and there was not any "technical" justification of the inequality of income or wealth.

"Thus our argument leads towards the conclusion that in contemporary conditions the growth of wealth, so far from being dependent on the abstinence of the rich, as is commonly supposed, is more likely to be impeded by it. One of the chief social justifications of great inequality of wealth is, therefore, removed" (Keynes, 1936, p. 373).

A few years after the General Theory was published, Keynes' analysis was included as a "special case" of the "Neoclassical Synthesis. "Keynesian economics" became a very different approach and the issue of income distribution and the economic intervention of the State became less important for economists.

Keynes, in his critic to the pre-Keynesian ideas, introduced many important concepts for a macroeconomic theory; among them uncertainty and disequilibrium were crucial but the Neoclassical Synthesis seemed to ignore them. In Keynes' view, a self regulated system had no place.

However, as it always occurs with every great book, the General Theory has more than one interpretation (actually it has many and it is nearly impossible to recognize the ideas of Keynes among the ideas of his exegetes). Clower (1965) and Leijonhufvud (1968) provided their view of the "Keynesian message"; for them Keynes must be read from a disequilibrium approach.

A more radical perspective, also critique of the Neoclassical Synthesis belongs to "post-Keynesians". 10 This group of authors, despite their heterogeneity, can refered to as a "school". They consider that Neoclassical Synthesis betrays and distorts the analysis and the last conclusions of Keynes. An excellent summary of the different interpretations of Keynes's work can be seen in Coddington (1976).

In the 1970s the New Classic School ${ }^{11}$ of economics was born; for these economists income distribution is not an important issue. The most famous member of this school has expressed it very clearly and equaly crudely:

"Of the tendencies that are harmful to sound economics, the most seductive, and in my opinion the most poisonous, is to focus on questions of distribution" (Lucas, 2004).

However, after the second World War, some studies had focused on economic inequality. The remarkable economist Simon Kuznets was a forerunner and in 1955 he published his well-known paper "Economic Growth and Income Inequality". He tried to answer these two following questions:

"Does inequality in the distribution of income increase or decrease in the course of a country's economic growth? What

\footnotetext{
9 The expression "Neoclassical Synthesis" was a way to join Neoclassical theory with the ideas of Keynes. This view, that became the new paradigm, is associated to the names of Hicks, Hansen and Samuelson.

10 The most salient features of this approach can be seen in Loasby (1976) and Davidson (1983). Many of Post-Keynesian opinions are published in the Journal of Post-Keynesian Economics founded by Weintraub and Davidson in 1978.

${ }_{11}$ The principal members of this school are, among others, Robert Lucas, Thomas Sargenti, Robert Barro and Neil Wallace.
} 


\section{Articles}

factors determine the secular level and trends of income inequalities?" (Kuznets, 1955, p. 1).

Kuznets was very optimistic and answered that economic development would gradually solve the problem, as market forces first would increase and then decrease economic inequality. Market forces will be able to solve economic inequality while the countries begin their industrial and economic development; therefore a graphic of inequality would look like a "inverted U".

"In concluding this paper, I am acutely conscious of the meagerness of reliable information presented. The paper is perhaps 5 per cent empirical information and 95 per cent speculation, some of it possibly tainted by wishful thinking" (Kuznets, 1955, p. 26).

Despite this paragraph quoted above, many mainstream economists assumed that inequality was not a great problem and that the market forces would solve it in the best possible way.

However, as it always occurs, economic reality showed that the optimistic view of the "inverted U curve" was not right. History and statistical evidence from various regions of the world (e.g. Latin America) showed that the relationship suggested by Kuznets'curve did not exist.

When inequality began to rise, during last decades of the $20^{\text {th }}$ century, new works tried to answer the "old" questions. Do free market forces drive the world to a more egalitarian economic situation? or Is the economic inequality an unavoidable consequence of capitalism?

To answer these questions Piketty (2014) is a great contribution.and not only discussed why inequalities exist, but how to resolve them (for example with tax policies).

Piketty's best-seller book has been very important to reintroduce inequality not only as one of the economists' concerns but also as a topic of public debate. Using a big number of statistical information, Piketty concluded that there is a relationship between the rate of return on capital and the rate of growth of national income. If the first is greater than the second (when the economy is growing slowly), inequality rises (and it affects democracy too).

There are many other very important contributions that must be cited, given that new investigations with better information and statistical tools have been made.

Recently Branko Milanovic (2016) discussed the relationship between globalization and inequalities.

Amartya Sen, quoted at the beginning of this paper, has produced not only very relevant analysis but has contributed to develop new methods to measure poverty and inequality. His books, for example On Economic Inequality (Sen, 1972) and Economic Inequality Reexamined (Sen, 1992) are already "classical opus" of inequality problems.

It is also necessary to highlight the prolific work of Anthony B. Atkinson (Atkinson, 2015). He not only analysed the problem of inequality and poverty, but also advocated for radical political measures to fight inequality. ${ }^{2}$

\section{A FINAL REFLECTION}

To explain the evolution of the levels of global economic inequality, many causes that operate in different ways must be considered.

In recent years, in many countries, there has been a significant increase in income, but inequality has not shown the same trend. This situation means that nation al policies can

12 His fifteen proposals from the book are also available at: https://www.tony-atkinson.com/ the-15-proposals-from-tony-atkinsons-inequality-what-can-be-done/ 
contribute to improving or to worsening the level of inequality.

Can the economists help in the fight against inequality? Is there some moral imperative to do that? Both questions have affirmative answers; not "scientific" answers but Moral and Human ones. Economists have the obligation to deepen studies and cooperate with researchers from other disciplines to better understand the dynamics of poverty and economic inequality. This way we can collaborate more effectively to design public policies that deal with the problem. ${ }^{13}$ The second question can be answered with this famous and often quoted phrase:

"Economists set themselves too easy, too useless a task if in tempestuous seasons they can only tell us that when the storm is long past the ocean will be flat again" (Keynes, 1923. Chapter III, p. 80).

\section{REFERENCES}

Aristotle (330-323 B.C.). "Politics. A Treatise on Government". The Project Gutenberg EBook of Politics. http://www.gutenberg.org/ files/6762/6762-h/6762-h.htm [last accessed 4 Nov. 2020].

Atkinson, A. B. (2015). "Inequality - What Can Be Done?". Harvard University Press.

Bray, J. F. (1839). "Labour's Wrongs and Labour's Remedy; or the Age of Might and the Age of Right". Published by D. Green, Briggate. Birmingham.

Clower, R. (1965). "The Keynesian Counterrevolution: A theoretical appraisal", in Hahn and Matthews, eds, Theory of Interest Rates. Macmillan. London.

Cohen Avi J. and Harcourt G. C. (2003). "Whatever Happened to the Cambridge
Capital Theory Controversies?". Journal of Economic Perspectives, 2003, vol. 17(1), pp. 199-214.

Fourier, C. (1822). "Traité de l'association domestique agricole ou attraction industrielle". Available at: https://archive.org/details/bub_ gb_7Qc-AAAAcAAJ .[last accessed 4 Nov. 2020].

Gray, J. (1825) [1972]: "Lectures on Human Happiness". Routledge (New Edition).

Hodgskin, T. (1825) (1922). "Labour Defended against the Claims of Capital". The Labour Publishing Company Ltd. London. Available at: http://davidmhart.com/liberty/English ClassicalLiberals/Hodgskin/Hodgskin 1825LabourDefended.pdf [last accessed 4 Nov. 2020].

Jevons, W. (1871). "The Theory of Political Economy". Macmillan and Co. London. Available at: https://ia802708.us.archive. org/32/items/theoryofpolitica00jevouoft/ theoryofpolitica00jevouoft.pdf [last accessed 4 Nov. 2020].

Keynes, J. M. (1923). "A Tract on Monetary Reform". Macmillan and Co. Limited. London.

Keynes, J. M. (1933). "Essays in Biography". Macmillan and Co. Limited, pp. 95-149.

Keynes, J. M. (1936). "The General Theory of Employment, Interest and Money". Macmillan and Co. Limited. London.

Kuznets, S. (1955). "Economic Growth and Income Inequality". The American Economic Review. Vol. 45(1), pp. 1-28.

Leijonhufvud, A. (1968). "On Keynesian Economics and the Economics of Keynes: A study in monetary theory". New York and London: Oxford University Press.

\footnotetext{
${ }^{13}$ It is worth mentioning the relevant work of World Wealth and Income Database (WID) project. It is an open source on line database of the distribution of income and wealth in many countries.

${ }^{\text {It }}$ can be see at the web site: https://wid.world/\#Home
} 


\section{Articles}

Lucas, R. (2004). "The Industrial Revolution: Past and Future". 2003 Annual Report Essay of the Federal Reserve Bank of Minneapolis.

Malthus, R. T. (1798). "An Essay on the Principle of Population". Available at: http:// www.gutenberg.org/files/4239/4239h/4239-h.htm [last accessed 4 Nov. 2020].

Marshall, A. (1890) [1920]. "Principles of Economics". $8^{\text {th }}$ edition. Macmillan and Co. London. Available at: https://eet.pixel-online. org/files/etranslation/original/Marshall,\%20 Principles\%20of\%20Economics.pdf [last accessed 4 Nov. 2020].

Marx, K. (1891). "Critique of the Gotha Programme". (Published by F. Engels). Available at: http://www.slp.org/pdf/marx/ gotha_prgm.pdf [last accessed 4 Nov. 2020]. Menger, C. (1871). "Principles of Economics". Available at: https://mises.org/library/ principles-economics. [last accessed 4 Nov. 2020].

Milanovic, B. (2016). "Global Inequality. A New Approach for the Age of Globalization". Harvard University Press. Cambridge, Massachusetts.

Mill, J. S. (1848). "Principles of Political Economy with some of their Applications to Social Philosophy". Ed. William J. Ashley (London: Longmans, Green and Co., 1909, $7^{\text {th }}$ ed.). Available at: https://oll.libertyfund. org/titles/mill-principles-of-political-economyashley-ed [last accessed 4 Nov. 2020].

Napoleoni, C. (1963). "Il pensiero economico del 900". Giulio Einaudi editore S. p. A. Torino.

Pareto, V. (1896-1897). "Cours d'Économie Politique. Professé a l'Université de Lausanne". F. Rouge, Éditeur, Librairie de l'Université.

Piketty, T. (2013) [2017]. "Capital in the Twenty-First Century". Harvard University Press. Cambridge, Massachusetts.

Pigou, A. C. (1920) [1932]. "The Economics Of Welfare". Macmillan and Co. London.
Available at: https://oll.libertyfund.org/titles/ pigou-the-economics-of-welfare? $q=$ pigou\# [last accessed 4 Nov. 2020].

Plato (356?B.C.). "Laws". Available at: https:// ryanfb.github.io/loebolus-data/L187.pdf [last accessed 4 Nov. 2020].

Proudhon, P.J. (1840). 'Qu'est-ce que la propriété ? ou recherches sur le principe du droit et du gouvernement. Premier Mémoire". Available at: https://cras31.info/IMG/pdf/ proudhon_la_proprietef.pdf [last accessed 4 Nov. 2020].

Ricardo, D. (1821)[2001]." On the Principles of Political Economy and Taxation". Batoche Books. Available at: https://socialsciences. mcmaster.ca/econ/ugcm/3/l3/ricardo/ Principles.pdf [last accessed 4 Nov. 2020].

Rosseau, J. J. (1754). "Discourse on Inequality". Available at: https://www.aub.edu. I b / f a s / c v s p / D o c u m e n t s / Discourseonlnequality.pdf879500092.pdf [last accessed 4 Nov. 2020].

Saint Simon, H. comte de. (1825). "Nouveau Christianisme: dialogues entre un conservateur et un novateur". Available at: https://archive. org/details/nouveauchristian01sainuoft [last accessed 4 Nov. 2020].

Say, J. B. (1803) [1971]. "A treatise on Political Economy. Or the Production, Distribution and Consumption of Wealth". Reprinted by Augustus M. Kelley Publishers. New York.

Sen, A. (1972). "On Economic Inequality". Oxford University Press. Claredon Press. Oxford.

Sen, A. (1992). "Inequality Reexamined". Oxford University Press. Claredon Press. Oxford.

Sismondi, J.C. (1819). "Nouveaux Principes d'Économie Politique ou de la richesse dans ses raports avec la population". Imprimerie Place De L'Odeon. Available at: 
http://www.ecn.ulaval.ca/ ^pgon/hpe/ documents/socialisme/Sismondi2_1819.pdf [last accessed 4 Nov. 2020].

Smith, A. (1776) [1976]: "An Inquiry into the Nature and Causes of the Wealth of Nations". Oxford University Press. Available at: http:// files.libertyfund.org/files/220/0141-02_Bk.pdf [last accessed 4 Nov. 2020].

Thompson, W. (1824). "An Inquiry into the Principles of the Distribution of Wealth Most Conducive to Human Happiness; applied to the Newly Proposed System of Voluntary Equality of Wealth". Longman, Hurst, Rees, Orme, Brown, and Green. London. Available at: https://ia800304.us.archive. org/19/items/inquiryintoprinc00thomuoft/ inquiryintoprinc00thomuoft.pdf [last accessed 4 Nov. 2020].

Torrens, R. (1834). "On wages and combination". Longman, Rees, Orme, Brown, Green, \& Longman. London. Available at: ht t ps://archive.org/details / onwagescombinati00torr [last accessed 4 Nov. 2020].

Walras, L. (1874) [1926]. "Éléments d'économie politique pure, ou théorie de la richesse sociale". L. Corbaz \& Cie. Lausanne. Available at: https://ia801402.us.archive.org/2/items/ Imentsdconomiep00walrgoog/Imentsdcono miep00walrgoog.pdf [last accessed 4 Nov. 2020]. 